\author{
Alexander Andrason \\ University of Stellenbosch \& University Complutense in Madrid \\ Department of Ancient Studies
}

\title{
Vilamovicean verbal system - Do the Preterite and the Perfect mean the same?
}

Keywords: Germanic linguistics, verbal system, perfect, past, endangered and minority languages

\section{Introduction - Vilamovicean and its verbal system}

Vilamovicean (Wymysöeryś [vimisør:I६]) is a Germanic language spoken in the south of Poland in the town of Wilamowice situated in the Western Galicia on the boundary with Silesia ${ }^{1}$. It is a descendant of Middle High German and it shares a common development with other Central East German daughter languages, like for instance Silesian and its dialects. Nowadays, Vilamovicean is probably the smallest Germanic language in the world. It is understood by approximately eighty persons, and actively spoken by no more than twenty speakers that are fully competent and preserve the pure version of Vilamovicean. Because nowadays Vilamovicean is spoken only by a small group of elderly native speakers (most of them are more than 80 years old), its future is in real danger.

The verbal system of Vilamovicean includes the following categories: tense (present, preterite and future), resultative (perfect) and possibly aspect

1 According to the administrative division Wilamowice constitutes a part of Województwo Śląskie (Silesian Province). 
(progressive). Moreover, there is a modal distinction between the indicative, the irrealis (subjunctive-conditional), and the imperative. Finally, Vilamovicean possesses two voices: active and passive. Not all of these categories have been fully grammaticalized. Some may be defined as core or central, while others are peripheral and show a lexical force rather than a grammatical function. Surprisingly, one may find among native speakers and scholars a widespread opinion claiming that two verbal grams ${ }^{2}$, i.e., the Preterite $^{3}$ and the Perfect, offer the same meaning, both indicating anterior events and situations (Kleczkowski 1920, Młynek 1907, Wicherkiewicz 2004). The impression one gets from the existing grammars is that the Perfect and the Preterite overlap semantically, and thus may be used interchangeably, one instead of the other. This article is aimed at analyzing similarities and differences in uses of the Perfect and Preterite in order to answer the question of whether these two grams have semantically converged into a "broad and general" past, and admit an indiscriminate mutual substitution. In other words: Do the Preterite and the Perfect mean the same ${ }^{4}$ ? In order to answer this question the author will first describe prototypical and less prototypical functions of the Vilamovicean Preterite (section 1), and then prototypical and less prototypical uses of the Perfect (section 2). Finally, in the last part (section 3), the

2 In general, the term 'verbal gram' approximates the notion of verbal grammatical construction and is frequently employed to refer to formations that reflect any phase of the prototypical grammaticalization path, from lexical periphrastic inputs (peripheral grams) to central synthetic categories (core grams). During the grammaticalization process, grams 'travel' from the periphery to the centre of the verbal system acquiring and combining meanings that correspond to various typologically universal semantic domains like taxis, aspect, tense, and mood. Thus, the traditional concepts of taxis, aspect, tense, and mood are used to characterize the functional content of grams. Consequently, a category which, in a given language, is labeled 'present tense' may choose its actual meaning from various functional fields and thus provide several temporal, aspectual, and modal values (Dahl 2000: 7).

3 The constructions labeled here as Preterite and Perfect formally correspond to similar grams in other Germanic languages. The Vilamovicean Preterite yhy koüft 'I bought' morphologically matches the common Germanic simple past, as for instance in German Ich kaufte 'I bought'. The Perfect yhy ho gykoüft or yhy bej gykuma corresponds to the typical analytic participial perfect, e.g. German Ich habe gekauft 'I have bought' and Ich bin gekommen 'I have come'.

${ }^{4}$ We must emphasize that scholars have not paid sufficient attention to this issue and the above mentioned observations on the Perfect and Preterite found in the literature, are in fact limited to a few sentences (cf. Młynek 1907: 13, Wicherkiewicz 2004, and Kleczkowski 1920: 4; 142). Lasatowicz (1992) completely ignores this question. 
uses of the two constructions will be contrasted, and conclusions will be presented.

This paper is based upon the field research and all quoted examples come from the database collected by the author in collaboration with Tymoteusz Król during their research in Wilamowice in June 20085. To the research on the Preterite and Perfect nine persons with the best proficiency in Vilamovicean were chosen: Elżbieta Młynarska 'Milerka' (born 1921), Helena Biba 'Płacznik' (1922), Anna Zejma 'Luft' (1923), Elżbieta Matysiak, 'Hala-Mockii' (1924), Waleria Brzezina 'Cepok' (1925), Rozalia Hanusz 'Linkuś' (1926), Stanisław Fox 'Luft' (1926), Anna Fox 'Luft' (1927), and Helena Rozner 'Biba' $(1928)^{6}$. It should be observed that except several poems composed by Florian Biesik in the beginning of the $20^{\text {th }}$ century, there is no real Vilamovicean literature ${ }^{7}$. In consequence, the field work and recording of speakers is the only reliable source of the contemporary shape of the language, which could also suggest what the usage might have been before Vilamovicean began to decline, i.e., before the Second World War.

Before analyzing the values and functions of both constructions, a few words should be dedicated to the gram usually referred to as perfect. In this article, following Jónsson (1992: 129-145) and McCawley (1971), the term 'present perfect' will be split into four categories: resultative $^{8}$ (1a), universal ${ }^{9}$

5 The analysis and description of the Vilamovicean verbal system presented here form a part of a wider research project led by the author in collaboration with Tymoteusz Król that aims at writing a compendious grammar of Vilamovicean.

6 The relative frequency of uses of the Preterite and Perfect has been based on examples provided by the above mentioned speakers. Such a database (based on nine persons) is certainly limited and thus, frequency given in this article should be taken as guiding and orientative. Hence, in the main text of the article, the terms 'common' $(50 \%$ and more), 'not infrequent' (less than $50 \%$ but more than 10\%), and 'infrequent' $(10 \%$ and less) will be used. The exact statistical information will be provided in the corresponding footnotes. Furthermore, it should be noted that the statistical digits are given approximately, for the sake of clarity, in intervals of five, i.e. 0 - 5 -10 -15 etc. Finally, the numbers that reflect the real frequency will be presented at the end of section 3 in table 3 .

${ }^{7}$ For the review of all written records of the Vilamovicean language see Wicherkiewicz (2004). Additionally, it should be noted that some songs were recently published by Danek (2007), Gara (2006), and Dobczyński (2002).

8 The resultative perfect emphasizes the current (present) results of a prior (past) action.

9 In this meaning the perfect indicates an action or state that holds without interruption from a moment in the past to the present time. 
(inclusive) (1b), experientia $1^{10}(1 \mathrm{c})$, and hodiernal ${ }^{11}$ (1d). Moreover, the resultative perfect will be treated as a distinct category from the resultative proper, which constitutes the output of the resultative path ${ }^{12}$ and may be semantically defined as a resultative non-dynamic (thus static / possessive) present (1e) ${ }^{13}$.

(1) a. I cannot come to your party - I have caught the flu.

b. I have known Max since 1960

c. I have read 'Principia Mathematica' five times

d. I bought the car this morning / Sp. He comprado el coche esta mañana

e. I have the letter written / Sp. Tengo escrita la carta (Maslov 1988: $74)^{14}$

${ }^{10}$ In this function the perfect indicates that the subject has an experience of having performed a given action. Put differently, the event is expressed as an experience which occurred at least once, and which might have been repeatable. It is frequently expressed without specifying any particular location in time.

11 The hodiernal perfect expresses past actions that were accomplished within the last 24 hours. In English, one uses the Simple Past in this function This morning I bought a newspaper. However, in Spanish the perfect (Preterito Perfecto) may be used Esta mañana he comprado un periódico.

12 On the resultative path see Maslov (1988), Nedjalkov, Jaxontov (1988), Bybee, Perkins, Pagliuca (1994), Dahl (2000), and Squartini \& Bertinetto (2000). This path may briefly be defined as a development whereby a resultative proper construction acquires anterior and perfect meanings turning subsequently into the perfective aspect and finally into the simple and general past.

13 It should be noted that the mentioned types of the perfect are not limited to the English language and, therefore, I do not intend to describe the Vilamovicean constructions through the English Perfect Tense (this becomes evident if one takes into consideration the hodiernal perfect function, which cannot be expressed by the Present Perfect in English). As observed by Bybee, Perkins, Pagliuca (1994), Dahl (2000), Lindstedt (2000), Squartini, Bertinetto (2000), and Mitkovska, Bužarovska (2008), the existential/possessive, resultative, inclusive, experiential and hodiernal perfects are typologically universal in the sense that they, all together and subsequently, form the resultative path. This, on the other hand, does not mean that the grams that are called 'perfects' in different languages, convey all the prototypical perfect meanings.

14 Finally, it must be emphasized that this is a purely synchronic study, which is limited to the description of the present situation of the Vilamovicean language. The question of the similarity and possible interferences with German and its dialects, as well as with the Polish language - highly interesting in itself - will be entirely disregarded. 


\section{Vilamovicean Preterite}

In grammar books, the preterite is defined as an unmarked tense of past events with no direct relation to the present situation. It is therefore not surprising that the Vilamovicean Preterite, as preterites in numerous Modern and Old Germanic languages, may express remote past events (2):

(2) Der jyśty kyng boüt ${ }^{15}$ Krök the first king built Cracow The first king [of Poland] built Cracow

The Preterite is also frequently used as a simple past with explicit anterior adverbs or in the explicit past context (3) ${ }^{16}$ :

(3) Yh go mih oüs hefa jür y dom

I gave myself out many years ago

I got married a long time ago

Since there is no fully grammaticalized imperfective or progressive past, like for example in English I was talking, or in Icelandic ég var að segja, past events and actions expressed by the Vilamovicean Preterite may also have durative and habitual value (4 and 5) ${ }^{17}$ :

(4) Wi wiöeh klin kuzt yh myta ełdyn wymysiöeryś

when was-I little talked I with-the parents Vilamovicean

When I was a child, I talked to my parents in Vilamovicean

(5) Wi dy krig wiöe, do ging yh y dy süul

when the war was then went I to the school

During the war, I went / was going to school

15 The Vilamovicean Preterite and Perfect forms will be given in bold type.

16 The Preterite may be found in $70 \%$ of cases where the remote or explicit past actions are expressed. The Perfect appears in 30\% of such instances.

17 The Preterite appears in $90 \%$ of instances where the durative meaning is conveyed. The Perfect may uniquely be found in $10 \%$. 
The above mentioned uses of the Preterite are regular and correspond to the simple past in English, and Icelandic, and in the case of the durative meaning to the simple past in Scandinavian and Old Germanic languages (cf. the Gothic or Swedish preterite that may provide both simple past and habitualdurative meaning).

Furthermore, the Preterite is frequently used for description of hodiernal past events, i.e., past events that have occurred within 24 hours, cf. (6) ${ }^{18}$ :

(6) Hoüts mügiys koüft yh a brut

today morning bought I a/one bread

Today in the morning I bought a loaf of bread

There are, however, other values of the Vilamovicean Preterite that are less prototypical - these values correspond rather to the semantic sphere of the present perfect than to that of the preterite. Namely, the Vilamovicean Preterite commonly provides experiential perfect meaning (7):

(7) Yhy wiöe ni kamöł hynder dy gronc

I was not never outside the border

I have never been abroad

It must be emphasized that in this function, the Preterite is by far more common than the expected Perfect (see the next section). The Preterite may also offer resultative perfect meanings ( 8,9 and 10). However, in this usage the Perfect is significantly more common ${ }^{19}$.

(8) Eta kom der nökwer

just arrived the neighbor

The neighbor has just arrived

(9) Yh fergas hefa wymysiöeryśy wiytyn

I forget many Vilamovicean words

I have forgotten a lot of words in Vilamovicean

18 The Preterite is used in $80 \%$ of instances and the Perfect in $20 \%$.

19 The relative frequency of the Preterite and Perfect in the experiential and resultative perfect functions among our informers is the following: experiential perfect meaning: Preterite $80 \%$ - Perfect $20 \%$; resultative perfect meaning Preterite $40 \%$ - Perfect $60 \%$. 
(10) H-ho ka śłysułn boh ja felür

I-have no keys because-I them lost

I do not have the keys because I have lost them

Aside from the prototypical preterite uses, and the perfect values, the Vilamovicean Preterite can also be used in the sense of a pluperfect. Thus, the Preterite may function as the anterior to other past events, i.e., as a past that occurred before other past actions (11). This usage seems to be quite frequent even though other formations, especially the Perfect and the Pluperfect proper (yhy hot gymoht) are also possible and common:

(11) Hor śtürrw śun wi der dökter kom

he died before that the doctor came

He had died before the doctor came

Additionally, the Preterite may sometimes be used in the reported speech with the value of a past event presented from the already past perspective ${ }^{20}$. In this function it corresponds to the pluperfect in English or Icelandic (12):

(12) Hor kuzt do hor śun dos moht

he said that he already this did

He said that he had already done it

The prototypical and less prototypical uses and values of the Vilamovicean Preterite may be summarized in the following way (Table 1):

Table 1. The uses and values of the Vilamovicean Preterite

\begin{tabular}{|c|c|c|}
\hline \multicolumn{2}{|c|}{ Function } & Occurrence \\
\hline \multirow{3}{*}{$\begin{array}{l}\text { prototypical } \\
\text { preterite }\end{array}$} & Remote past & Common \\
\hline & Simple past & Common \\
\hline & Durative past & Common \\
\hline
\end{tabular}

${ }^{20}$ As far as pluperfect functions are concerned, the frequency of the Preterite and Perfect may be summarized in the following way: anterior to the past: Preterite $40 \%$ - Perfect 60\%; reported speech Preterite 25\% - Perfect $75 \%$. 


\begin{tabular}{||l|l|l||}
\hline \multicolumn{2}{|l|}{ Function } & \multicolumn{1}{c|}{ Occurrence } \\
\hline $\begin{array}{l}\text { prototypical } \\
\text { present perfect }\end{array}$ & Universal inclusive perfect & Never \\
\cline { 2 - 3 } & Experiential perfect & Common \\
\cline { 2 - 3 } & Hodiernal perfect & Common \\
\cline { 2 - 3 } & Resultative perfect & Not infrequent \\
\hline $\begin{array}{l}\text { prototypical } \\
\text { pluperfect }\end{array}$ & Anterior to past & Not infrequent \\
\cline { 2 - 3 } & Reported speech & Not infrequent \\
\hline
\end{tabular}

\section{Vilamovicean Perfect}

As was the case of the Preterite, also the Vilamovicean Perfect displays both prototypical perfect values as well as meanings that are normally conveyed by other categories. Among prototypical perfect values only the resultative perfect meaning is commonly expressed by the Vilamovicean Perfect $(13,14$, and 15$)$. In this function, the Perfect is more frequently used than the Preterite ${ }^{21}$.

(13) Yhy ho wiytyn y wymysiöeryś fergasa cy kuza I have words in Vilamovicean forgotten to speak I have forgotten a lot of words in Vilamovicean

(14) Yh ho ka śłysułn bo yh ho ja felün I have no keys because I have them lost I do not have the keys because I have lost them

(15) Yta ej grod gykuma der nökwer just has already come the neighbor The neighbor has just arrived

Other typical perfect values (experiential and universal) are less commonly provided by the Perfect. The experiential perfect is most frequently ex-

21 According to our data the Preterite appears in $40 \%$ of the cases while the Perfect in $60 \%$. 
pressed by the Preterite 22 (7), while the universal inclusive perfect is always expressed by the Present ${ }^{23}(16)$ :

(16) Yh wön y Wymysoü wi'h uf dy wełt kom

I live in Wilamowice since I on the world came

I have lived in Wilamowice since I was born

As we have mentioned above, the hodiernal perfect is regularly expressed by the Preterite, cf. (6) above. However, the Perfect may also be used in order to describe hodiernal events $(18)^{24}$ :

(18) Hoüts mügies ho yh gykoüft a brut

today in-the-morning have I bought (a) bread

Today in the morning I bought a loaf of bread

Among non-prototypical uses of the Perfect there is one that seems to be fairly frequent. Namely, the Perfect is commonly used in order to refer to remote past or simple events even though the Preterite still seems to be more frequent ${ }^{25}$, cf. (18):

(18) Der jyśty kyng höt ufgyboüt Krök

the first king has built Cracow

The first king of [Poland] built Cracow

As the Preterite, also the Perfect may sometimes be used with durative or habitual force (19). In this function the Preterite is, however, by far more common $^{26}$.

22 In the function of the experiential perfect, the Preterite appears in $80 \%$ of cases and the Perfect in $20 \%$.

23 In this aspect, the Vilamovicean language coincides with German Ich kenne ihn seit 1960 'I have known him since 1960', Dutch We zijn al twee maanden in Nederland 'We have been in the Netherlands for two months', and Polish Mieszkam w Wilamowicach od wojny 'I have lived in Wilamowice since the war'.

24 The Preterite is used in $80 \%$ of instances and the Perfect in $20 \%$.

25 The Preterite may be found in $70 \%$ of cases where explicit past or remote actions are expressed. The Perfect appears in $30 \%$ of such instances.

${ }^{26}$ According to our database, the Preterite appears in $90 \%$ of instances where the durative meaning is conveyed, while the Perfect may uniquely be found in $10 \%$. 
(19) Wi wiöe yh klin ho yh gykuzt myt majny ełdyn wymysiöeryś when was I little have I talked with my parents Vilamovicean When I was a child, I talked to my parents in Vilamovicean

Furthermore, the Perfect is extremely frequent in the function of the pluperfect both presenting an action as anterior to other past events (20 and 21), and in the reported speech (22 and 23). These two pluperfect values are more commonly expressed by the Perfect than by the Preterite ${ }^{27}$. However, Vilamovicean has also a pluperfect proper that frequently appears in past perfect functions.

(20) Hor ej gyśtürwa wajł der dökter kom

he is died as before the doctor came

He had died before the doctor came

(21) Gestyn wi ej kuma dy nökweryn, hoh śün ufgyroümt dy kyh yesterday as is come the neighbor have-I already cleaned the kitchen Yesterday, when the neighbor came, I had already cleaned the kitchen

(22) A ziöet do ja śun höt dos gymoht he said that he already has this done He said that he had already done it

(23) A ziöet do a śun höt gyłoza dos bihła he said that he already has read this book He said that he has read this book

Furthermore, there are two meanings where the Perfect does not express any type of anterioty (remote or recent, punctual or durative, and unconnected to the time of enunciation or, on the contrary, relevant for the present state of affairs). In these non-anterior roles, the Perfect functions either as the present stative resultative - i.e., the resultative proper - (24), or as the immediate future $(25)^{28}$.

27 The Preterite is used to express the past anteriority in $40 \%$ while Perfect may be found in $60 \%$ of instances. In the reported speech, the Preterite functions as the pluperfect in $25 \%$ and the Perfect in $75 \%$ of cases.

28 In both functions the use of the Preterite is ungrammatical. 
(24) Yhy ho dy kyh ufgyroümt

I have the kitchen already cleaned

(Polish: Mam kuchnię już posprzątaną)

(25) Yhy ho dos gymoht y oügabłyk

I have done it in a little while!

(Polish: Za chwilę mam to zrobione!)

The prototypical and less prototypical uses and values of the Vilamovicean Perfect may be summarized in the following table (Table 2) below ${ }^{29}$ :

Table 2. The uses and values of the Vilamovicean Perfect

\begin{tabular}{||l|l|l||}
\hline \multicolumn{2}{|c|}{ Function } & \multicolumn{1}{c|}{ Occurrence } \\
\hline \multirow{4}{*}{ prototypical preterite } & Remote past & Not infrequent \\
\cline { 2 - 3 } & Simple past & Not infrequent \\
\cline { 2 - 3 } & Durative past & Infrequent \\
\hline prototypical perfect & Universal inclusive perfect & Never \\
\cline { 2 - 3 } & Experiential perfect & Not infrequent \\
\cline { 2 - 3 } & Hodiernal perfect & Not infrequent \\
\cline { 2 - 3 } & Resultative perfect & Common \\
\hline prototypical pluperfect & Anterior to past & Common \\
\cline { 2 - 3 } & Reported speech & Common \\
\hline
\end{tabular}

${ }^{29}$ In table 2 (and also in table 3) the immediate future function has been defined as a realization of one of the prototypical resultative proper meanings. This is true because of the fact that in this role the Perfect does not denote anterior (from the speaker's perspective) events, and can be understood as an extension of the original resultative present to the future context. It should be observed that the verb in the simple present (as is the case of the auxiliary hon in our examples) may indicate both present and future events. However, the Vilamovicean Perfect in the immediate future function may also be used with the dynamic and not possessive meaning. Typologically, the Vilamovicean Perfect corresponds to the Passé Composé in French that besides being a perfect (anterior) and past gram, may also function as a possessive resultative as well as an immediate future (both with possessive and dynamic value) (Grevisse 1975). 


\begin{tabular}{|l|l|l|}
\hline \multicolumn{2}{|c|}{ Function } & Occurrence \\
\hline $\begin{array}{l}\text { prototypical resultative } \\
\text { proper }\end{array}$ & Possessive resultative proper & Common \\
\cline { 2 - 3 } & Immediate future & Common \\
\hline
\end{tabular}

\section{Conclusion}

Let us first summarize the evidence. In the majority of the above-mentioned uses, the Preterite and the Perfect overlap - namely, the two grams may show preterite, perfect and pluperfect values. The only difference between the two categories lies in the frequency of determined uses. For example, both the Preterite and the Perfect may provide the resultative and durative-habitual past significance, but while the Perfect gives the resultative meaning significantly more often than the Preterite, the Preterite is a much more common expression of the habitual past than the Perfect. There are, however, two meanings that are reserved for the Perfect and never displayed by the Preterite, i.e., the present stative (non-dynamic and/or possessive) resultative meaning - i.e., the resultative proper - (24), and the future (both stative and dynamic) meaning (25). In the examples (24) and (25) the Preterite is impossible. In the example (25) one may uniquely use the Perfect and the Future, either the Simple Future (analytical future with the auxiliary won) or the Future Perfect (won hon gymoht).

All above-mentioned meanings that are displayed by the Perfect or the Preterite, as well as their respective dominant expression may be summarized in the following table (Table 3):

Table 3. Meanings and their dominant forms

\begin{tabular}{|c|c|c|c|c|}
\hline \multicolumn{2}{|c|}{ Function } & \multirow{2}{*}{$\begin{array}{c}\begin{array}{c}\text { Dominant } \\
\text { construction }\end{array} \\
\text { Preterite }\end{array}$} & \multirow{2}{*}{$\begin{array}{c}\begin{array}{c}\text { Relative } \\
\text { frequency }\end{array} \\
\begin{array}{c}\text { Preterite : } \\
\text { Perfect }\end{array} \\
70 \%: 30 \%\end{array}$} & \multirow{2}{*}{$\begin{array}{c}\text { Real frequency } \\
\begin{array}{c}\text { Preterite : } \\
\text { Perfect }\end{array} \\
13: 5\end{array}$} \\
\hline prototypical & Remote past & & & \\
\hline & Simple past & Preterite & $70 \%: 30 \%$ & $32: 13$ \\
\hline & Durative past & Preterite & $90 \%: 10 \%$ & $33: 3$ \\
\hline
\end{tabular}




\begin{tabular}{|c|c|c|c|c|}
\hline \multicolumn{2}{|c|}{ Function } & \multirow{2}{*}{$\begin{array}{c}\begin{array}{c}\text { Dominant } \\
\text { construction }\end{array} \\
\text { Present }\end{array}$} & \multirow{2}{*}{$\begin{array}{c}\begin{array}{c}\text { Relative } \\
\text { frequency } \\
\text { Preterite : } \\
\text { Perfect }\end{array} \\
0 \%: 0 \%\end{array}$} & \multirow{2}{*}{$\begin{array}{c}\text { Real frequency } \\
\text { Preterite : } \\
\text { Perfect } \\
-\end{array}$} \\
\hline $\begin{array}{l}\text { prototypical } \\
\text { present perfect }\end{array}$ & $\begin{array}{l}\text { Universal } \\
\text { perfect }\end{array}$ & & & \\
\hline & $\begin{array}{l}\text { Experiential } \\
\text { perfect }\end{array}$ & Preterite & $80 \%: 20 \%$ & $21: 6$ \\
\hline & $\begin{array}{l}\text { Hodiernal } \\
\text { perfect }\end{array}$ & Preterite & $80 \%: 20 \%$ & $22: 5$ \\
\hline & $\begin{array}{l}\text { Resultative } \\
\text { perfect }\end{array}$ & Perfect & $40 \%: 60 \%$ & $19: 26$ \\
\hline \multirow{2}{*}{$\begin{array}{l}\text { prototypical } \\
\text { pluperfect }\end{array}$} & Anterior to past & Perfect & $40 \%: 60 \%$ & $11: 16$ \\
\hline & $\begin{array}{l}\text { Reported } \\
\text { speech }\end{array}$ & Perfect & $25 \%: 75 \%$ & $7: 20$ \\
\hline \multirow{2}{*}{$\begin{array}{l}\text { prototypical } \\
\text { resultative } \\
\text { proper }\end{array}$} & $\begin{array}{l}\text { Resultative } \\
\text { proper }\end{array}$ & Perfect & $0 \%: 100 \%$ & $27: 0$ \\
\hline & $\begin{array}{l}\text { Immediate } \\
\text { future }\end{array}$ & Perfect & $0 \%: 100 \%$ & $27: 0$ \\
\hline
\end{tabular}

${ }^{1}$ It should be emphasized that these numbers must not be taken strictly and rigorously. They are presented uniquely as results that emerge from our limited database built on nine native Vilamovicean speakers. Future research may modify their exact shape, but supposedly the general tendencies should be conserved.

The analysis of the data leads to the conclusion that the two grams, i.e., the Preterite and the Perfect are not semantically and functionally identical. The Preterite predominates in all preterite functions as well as in two perfect uses, i.e., as the existential and hodiernal perfect. On the other hand, the Perfect must appear in two resultative proper functions, i.e., as the possessive stative and future - here the Preterite cannot be used. Furthermore, it predominates in all pluperfect uses as well as in the function of a resultative perfect. In consequence, we may affirm that the Preterite, being an explicit and general expression of the past, may appear in all temporally past contexts whether or not they are relevant for the current state of affair, with both durative and punctual meaning, and referring to remote and recent events. Conversely, the Perfect is principally an overt expression of the resultativity and accomplishment, and may be used with the past, present and future time reference. Consequently, 
the Preterite will be incompatible with present and future uses (cf. the possessive resultative proper and the immediate future) while the Perfect will rarely appear in the durative context.

\section{Bibliography}

Bybee J., Perkins R., Pagliuca W., 1994, The Evolution of Grammar, Chicago-London: The University of Chicago Press.

DAнL Ö., 2000, The Tense and Aspect Systems of European Languages in a Typological Perspective, in: Ö. Dahl (ed.), Tense and Aspect in the Languages of Europe, Berlin-New York: Mouton de Gruyter, p. 3-25.

DAHL Ö., (ed.), 2000, Tense and Aspect in the Languages of Europe, Berlin-New York: Mouton de Gruyter.

DaneK J., 2007, Wymysöjer śtytta, Wilamowice: Miejsko-Gminny Ośrodek Kultury.

DobczyŃski W., 2002, Śpiewnik Gminy Wilamowice, Wilamowice: Gmina Wilamowice.

GARA J., 2006, Zbiór piosenek wilamowskich, Wilamowice.

Grevisse M., 1975, Le bon usage, Gembloux: Éditions J. Duculot.

Jónsson J. G., 1992, The Two Perfects of Icelandic, Íslenskt mál 14, p. 129-145.

Kleczkowski A., 1920, Dialekt Wilamowic w zachodniej Galicji. Fonetyka i fleksja, Kraków: PAN.

Lasatowicz M., 1992, Die deutsche Mundart von Wilamowice zwischen 1920 und 1987, Opole: Wyższa Szkoła Pedagogiczna.

LinDSTEDT J., 2000, The perfect - aspectual, temporal and evidential, in: Ö. Dalh (ed.), Tense and aspect in the languages of Europe, Berlin-New York: Mouton de Gruyter, p. 365-383.

Maslov J., 1988, Resultative, Perfect and Aspect, in: V. Nedjalkov (ed.), Typology of resultative constructions, Amsterdam-Philadelphia: John Benjamins Publishing Company, p. 63-85.

McCawley J. D., 1971, Tense and Time Reference in English, in: C. J. Filmore, D. T. Langendoen (eds.), Studies in Linguistics and Semantics, New York: Holt, Rinehart and Winston.

Mitkovska L., Buzarovska E., 2008, On the use of the habere-perfect in journalistic and administrative style, in: Z. Topolińska, E. Bužarovska (eds.), Language Typology and Universals, Berlin: Akademie Verlag, p. 128-138.

MŁynek L., 1907, Narzecze wilamowickie, Tarnów: J. Pisz. 
Nedjalkov V., Jaxontov S., 1988, The Typology of Resultative Constructions, in: V. Nedjalkov (ed.), Typology of resultative constructions, Amsterdam-Philadelphia: John Benjamins Publishing Company, p. 3-63.

Squartini M., Bertinetto P. M., 2000, The Simple and Compound Past in Romance Languages, in: Ö. Dahl (ed.), Tense and Aspect in the Languages of Europe, Berlin, New York: Mouton de Gruyter, p. 403-439.

Wicherkiewicz T., 2004, The Making of a Language, Trends in Linguistics. Documentation 19, Berlin-New York: Mouton de Gruyter.

\section{Wilamowski system czasownikowy - czy preteritum i perfekt znaczą to samo? \\ (streszczenie)}

Celem niniejszej pracy jest opis podobieństw i różnic w użyciu dwóch konstrukcji czasownikowych w języku wilamowskim, tj. perfektu oraz preteritum. Aby zweryfikować powszechnie panującą opinię, według której obie konstrukcje są synonimiczne i odpowiadają szeroko rozumianemu czasowi przeszłemu, autor analizuje różnorodne przykłady ich użycia, zebrane w czasie badań terenowych w Wilamowicach w lipcu 2008 r. Wnikliwa analiza zgromadzonego materiału dowodzi, iż znaczenia i funkcje perfektu oraz preteritum nie są identyczne. Preteritum jest zwykle używane jako generalny czas przeszły oraz w dwóch znaczeniach typowych dla perfektu, tj. jako perfekt doświadczenia i jednodobowy perfekt. Wilamowski perfekt natomiast dominuje w znaczeniu czasu zaprzeszłego oraz w funkcji rezultatywnej. Ponadto, perfekt posiada dwa znaczenia, których preteritum nigdy nie jest w stanie oddać. Mianowicie, może być on użyty jako posesywny statyw oraz może także odnosić się do sytuacji dotyczących przyszłości. 